\title{
INVESTASI PENGEMBANGAN ENERGI ALTERNATIF CANGKANG SAWIT UNTUK MENURUNKAN BIAYA ENERGI DI PT XYZ
}

\author{
INVESTMENT OF ALTERNATIVE ENERGY DEVELOPMENT OF PALM OIL TO \\ REDUCE ENERGY COSTS IN PT XYZ
}

\author{
Rianto $^{*) 1}$, Bonar M Sinaga ${ }^{* *}$, dan Kirbrandoko $\left.{ }^{* * *}\right)$ \\ *) PT. Lasallefood Indonesia \\ Jl. Raya Jakarta Bogor KM 31 Cimanggis, Depok 16952 \\ **) Departemen Ekonomi Sumberdaya dan Lingkungan, Fakultas Ekonomi dan Manajemen, Institut Pertanian Bogor \\ Jl. Agatis, Kampus IPB Dramaga, Bogor 16680 \\ ${ }^{* * *)}$ Universitas Ibn Khaldun Bogor \\ Jl. Baru, Tanah Sereal, Bogor 16162
}

\begin{abstract}
The purpose of this study is to reduce energy costs by using alternative fuels. Next, calculate investment costs and operational costs. In addition, calculate the NPV, IRR, Payback Period, and engine sensitivity analysis with alternative fuels. The method used is exponential comparison, and to calculate the investment value, the net present value (NPV) method, internal rate of return (IRR), and the payback period are used while the prediction of the amount of production is calculated using a simple linear regression method. With the exponential comparison method, it is known that boiler engines with palm shell fuel rank first when compared to engines with gas, oil and coal fuel. Palm kernel shells have a higher caloric value than wood but are lower than coal. To be able to use palm kernel shells as fuel, the company must spend a high investment on the purchase of new machinery. The investment needed to procure a new engine is Rp.4.9 billion, while the NPV produced for 5 years is Rp.5.9 billion. By using a sensitivity analysis, there are some limits to the influential variable change, namely the maximum alternative fuel price is Rp1,128.00 per kilogram, a decrease in the amount of production not more than $44.22 \%$, the minimum gas fuel price is 6.02 USD per MMBTU and the minimum dollar exchange rate is IDR 9,795.00 per US dollar.
\end{abstract}

Keywords: NPV, IRR, alternative energi, MPE, palm shells

Abstrak: Tujuan penelitian ini adalah menurunkan biaya energi dengan menggunakan bahan bakar alternatif. Selanjutnya, menghitung biaya investasi dan biaya operasional. Di samping itu, menghitung NPV, IRR, Payback Periode, dan analisis sensitifitas mesin dengan bahan bakar alternatif. Metode digunakan perbandingan eksponensial, dan untuk menghitung nilai investasi dipergunakan metode net present value (NPV), internal rate of return (IRR), dan payback period sedang prediksi jumlah produksi dihitung menggunakan metode regresi linier sederhana. Dengan metode perbandingan eksponensial diketahui bahwa mesin boiler dengan bahan bakar cangkang sawit menempati urutan prioritas pertama jika dibandingkan dengan mesin dengan bahan bakar gas, minyak dan batu bara. Cangkang sawit memiliki nilai kalori yang lebih tinggi daripada kayu akan tetapi lebih rendah daripada batu bara. Untuk dapat menggunakan cangkang sawit sebagai bahan bakar, perusahaan harus mengeluarkan investasi yang tinggi untuk pembelian mesin baru. Investasi yang dibutuhkan untuk pengadaan mesin baru sebesar Rp4,9 milyar, sedang NPV yang dihasilkan selama 5 tahun sebesar Rp5,9 milyar. Dengan menggunakan analisis sensitivitas didapatkan beberapa batasan terhadap perubahan variabel yang berpengaruh yaitu harga bahan bakar alternatif maksimum adalah Rp1.128,00 per kilogram, penurunan jumlah produksi tidak lebih dari $44,22 \%$, harga bahan bakar gas minimum 6,02 USD per MMBTU dan kurs dolar minimum terhadap rupiah Rp9.795,00 per dolar amerika.

Kata kunci: NPV, IRR, energi alternatif, MPE, cangkang sawit

${ }^{1}$ Alamat Korespondensi:

Email: rianmtc@gmail.com 


\section{PENDAHULUAN}

Sektor industri di Indonesia telah berkembang demikian pesat dewasa ini. Pertumbuhan industri telah mengubah pola mata pencaharian masyarakat Indonesia dari masyarakat dengan mata pencaharian sebagian besar petani menjadi masyarakat berbasis industri. Dengan banyaknya industri yang tumbuh berkembang, persaingan produk menjadi semakin ketat. Rifai et al. (2016) menuliskan bahwa perusahaan yang mampu bersaing dalam pasar adalah perusahaan yang dapat menyediakan produk atau jasa berkualitas. Salah satu faktor yang menyebabkan harga suatu barang menjadi tinggi adalah biaya bahan bakar. Dengan naiknya harga bahan bakar minyak, kalangan industri mulai berpikir untuk beralih dari bahan bakar fosil menuju bahan bakar alternatif. Khaidir (2016) menuliskan bahwa bahan bakar alternatif merupakan bahan bakar yang dapat dipergunakan sebagai energi alternatif dalam rangka pemenuhan kebutuhan masyarakat dalam menjalankan roda kehidupannya. Saat ini telah banyak dikembangkan sumber bahan bakar alternatif untuk mengurangi ketergantungan terhadap bahan bakar dari hasil tambang. Bahan bakar alternatif yang saat ini banyak dipergunakan adalah biofuel, batu bara cair, dan cangkang sawit untuk bahan bakar boiler industri.

Mesin boiler merupakan mesin yang dipergunakan untuk membangkitkan uap dengan temperatur antara 170 sampai dengan 250 derajat celsius. Uap yang telah dihasilkan oleh boiler didistribusikan ke unit-unit di dalam perusahaan yang memerlukan uap sebagai media pemanas. Setelah dipergunakan, uap akan berubah fraksi menjadi air dengan temperatur antara 70 sampai 90 derajat celcius, air ini biasanya dipompa lagi ke mesin boiler untuk digunakan kembali menjadi uap lagi. Daur ulang air ini merupakan salah satu cara agar mesin dapat beroperasi dengan efisien. Wang et al. (2014) menuliskan bahwa efisiensi maksimum boiler dicapai saat jumlah oksigen di bawah 3,9\%. Sedang Hao (2014) menuliskan bahwa menurunkan temperatur gas buang dapat efektif mengurangi bahan bakar dan memperbaiki efisiensi boiler. Palaloi (2014) menuliskan bahwa peningkatan efisiensi boiler dapat diperoleh dengan jalan mengontrol komposisi udara dan bahan bakar, pemanfaatan gas buang untuk memanaskan udara pembakaran dan pemasangan economizer. Economizer merupakan salah satu alat yang dipergunakan untuk meningkatkan efisiensi mesin boiler. Penurunan efisiensi menyebabkan kerugian ekonomi dikarenakan harga bahan bakar semakin hari semakin meningkat (Ratnasari et al. 2014). Roslim et al. (2014) menyatakan bahwa twisted coil meningkatkan performa boiler dalam hal efisiensi. Cara selanjutnya dalam meningkatkan efisiensi mesin adalah dengan menambahkan komponen elektrik berupa embeded fuzzy module untuk mengatur aliran bahan bakar, uap dan udara (Hanamane et al. 2013). Selain faktor teknis, efisiensi boiler juga bisa disebabkan oleh faktor non teknis. Firdaus dan Sirait (2015) menyimpulkan bahwa efisiensi boiler akan terus menurun atau berbanding terbalik dengan meningkatnya produksi kapasitas uap. Faktor lain yang harus diperhatikan dalam pengadaan sebuah mesin adalah tata letak. Tata letak yang baik dapat membuat efisiensi peralatan lebih tinggi. Siregar et al. (2013) menuliskan bahwa suatu produksi yang memiliki jumlah mesin yang banyak dan aliran produksi yang panjang membutuhkan pengaturan tata letak dan pemindahan bahan yang efisien sehingga dapat mengurangi backtracking pada proses produksi. Faishol et al. (2013) menuliskan bahwa tata letak mesin yang tidak teratur dan jarak antar ruangan produksi yang cukup jauh dapat mengakibatkan proses produksi terganggu sehingga dapat memperlambat proses produksi. Yamashita et al. (2012) menuliskan bahwa tata letak yang diciptakan oleh sistem tata letak tidak hanya mempertimbangkan keefisienan dalam bekerja tetapi juga kemudahan kerja.

Cangkang sawit telah banyak dipergunakan untuk bahan bakar boiler sebagai pengganti bahan bakar minyak karena sumbernya yang melimpah. Haryanto et al. (2015) menuliskan bahwa cangkang sawit merupakan salah satu limbah industri sawit yang cukup banyak serta sampai saat ini belum dimanfaatkan secara optimal. Beberapa penelitian yang telah dilakukan hanya berfokus pada kalori yang terdapat dalam bahan bakar cangkang sawit dan belum meneliti investasi yang dibutuhkan untuk keperluan skala industri. Ruang lingkup dalam penelitian ini akan membahas investasi yang dibutuhkan jika sebuah perusahaan memanfaatkan cangkang sawit sebagai bahan bakar. Cara penyelesaian masalah dilakukan dengan studi literatur, observasi lapangan dan wawancara langsung dengan nara sumber. Tujuan yang ingin dicapai oleh suatu perusahaan dengan penggunaan bahan bakar alternatif adalah agar harga output uap yang dihasilkan oleh mesin boiler menjadi lebih murah sehingga dapat menurunkan biaya produksi yang dapat berdampak pada peningkatan keuntungan yang diperoleh perusahaan. 
Tujuan kedua yang ingin dicapai adalah menghitung layak atau tidak investasi mesin dengan bahan bakar alternatif tersebut dilakukan.

Untuk dapat mempergunakan cangkang sawit sebagai bahan bakar, perusahaan harus mengeluarkan investasi untuk pembelian mesin boiler. Menurut Jufrida et al. (2016) investasi merupakan salah satu unsur dalam meningkatkan kinerja ekonomi suatu negara. Sedang Nurlita (2014) menuliskan bahwa investasi merupakan pengeluaran atau pengorbanan sumber daya pada saat ini untuk memperoleh pengembalian di masa datang yang belum pasti besarannya. Analisis investasi diperlukan untuk mengetahui layak dan tidaknya suatu investasi dijalankan. Kasmir dan Jakfar (2013) menuliskan studi kelayakan bisnis adalah suatu kegiatan yang mempelajari secara mendalam tentang suatu usaha atau bisnis yang akan dijalankan dalam rangka menentukan layak atau tidak usaha tersebut dijalankan. Sedang Afiyah et al. (2015) menuliskan bahwa studi kelayakan proyek atau bisnis merupakan suatu kegiatan mengevaluasi, menganalisis, dan menilai layak atau tidak suatu proyek bisnis dijalankan.

Berdasarkan latar belakang dan permasalah serta kajian penelitian terdahulu maka penelitian ini bertujuan menurunkan biaya energi dengan menggunakan bahan bakar alternatif. Selanjutnya, menghitung biaya investasi dan biaya operasional. Di samping itu, menghitung NPV, IRR, Payback Periode, dan analisis sensitifitas mesin dengan bahan bakar alternatif.

\section{METODE}

Penelitian ini berlokasi di Depok yaitu di PT XYZ selama bulan April sampai November 2016, metode yang dipergunakan dalam penelitian ini adalah metode observasi lapangan dan wawancara langsung dengan narasumber. Dengan jumlah sampel yang sangat terbatas maka penelitian ini menggunakan metode purposive sampling. Peneliti melakukan observasi langsung terhadap mesin boiler yang dipergunakan dalam proses pembangkitan uap di PT XYZ. Peneliti mengobservasi operasional mesin yang saat ini dipergunakan di PT XYZ. Observasi meliputi pemakaian bahan bakar gas LNG harian, pemakaian air umpan dan jumlah uap yang didistribusikan ke unit produksi. Peneliti melakukan analisis terhadap biaya energi saat ini, investasi pengadaan mesin yang saat ini sedang digunakan, layout yang dimiliki oleh PT XZY dalam menempatkan unit mesin, biaya perawatan mesin dan biaya operasional mesin. Sedang untuk menghitung prediksi jumlah produksi 5 tahun ke depan dipergunakan metode regresi linier sederhana menggunakan data jumlah produksi PT XYZ dari tahun 2007 sampai dengan tahun 2016.

Untuk mendapatkan data tentang mesin boiler dengan bahan bakar alternatif, peneliti melakukan benchmarking ke PT.GG, PT BPE, dan PT TWA yang berlokasi di Tangerang. Jenis dan sumber data yang dipergunakan dalam penelitian ini dapat dilihat dalam Tabel 1.

Data - data yang telah didapat dilakukan analisis dengan bantuan software excel menggunakan metode perbandingan eksponensial untuk menentukan prioritas alternatif dari beberapa kriteria. Sedang analisis data finansial dilakukan dengan analisis net present value (NPV), internal rate of return (IRR), dan payback periode. Tabel perbandingan eksponensial menggunakan formula sebagai berikut:

$$
\text { Total nilai }\left(\mathrm{TN}_{\mathrm{i}}\right)=\sum_{\mathrm{j}=1}^{\mathrm{m}}\left(\mathrm{RK}_{\mathrm{ij}}\right)^{\mathrm{TKK}}
$$

Keterangan: $\mathrm{TN}_{\mathrm{i}}$ (Total nilai alternatif $\mathrm{ke}-\mathrm{i}$ ); $\mathrm{RK}_{\mathrm{ij}}$ (Derajat kepentingan relatif kriteria ke-j pada pilihan keputusan i); $\mathrm{TKK}_{\mathrm{j}}$ (Derajat kepentingan kriteria keputusan ke-j ; $\mathrm{TKK}_{\mathrm{j}}>0$; bulat); n (Jumlah pilihan keputusan); m (Jumlah kriteria keputusan).

Metode perbandingan eksponensial merupakan salah satu metode untuk menentukan urutan prioritas alternatif keputusan dengan kriteria jamak (Marimin 2004). Metode perbandingan eksponensial memberikan hasil yang lebih kontras jika dibandingkan dengan metode berbasis indeks kinerja yang lain. Langkah langkah dalam menggunakan metode perbandingan eksponensial adalah menyusun alternatif keputusan, menentukan kriteria, melakukan penilaian pada masing - masing kriteria, dan menghitung skor. Untuk menentukan skor dari tiap - tiap kriteria, penelitian ini menggunakan pendapat pakar yang telah menekuni bidang mesin dengan bahan bakar alternatif dengan masa kerja lebih dari 20 tahun. Dalam penelitian ini, alternatif yang dijadikan objek penelitian adalah mesin boiler dengan bahan bakar gas, alternatif, batu bara, dan minyak. Kriteria yang dipergunakan terdiri dari 8 kriteria yaitu investasi, pengoperasian, biaya perawatan dan perbaikan, efisiensi mesin, biaya bahan bakar, emisi pembakaran, penanganan sisa pembakaran, dan aspek 
K3. Sedangkan untuk analisis teknis dipergunakan formula sebagai berikut:

$\mathrm{E}_{\text {Out }}=\left(\mathrm{C}_{\mathrm{b}} \mathrm{X}\left(\mathrm{E}_{\mathrm{wst}}-\mathrm{E}_{\mathrm{wft}}+\mathrm{E}_{\mathrm{lh}}\right) / 4,1868\right.$

$\mathrm{F}_{\text {in }}=\left(\mathrm{E}_{\text {out }} / \eta_{\mathrm{b}}\right) / \mathrm{E}_{\text {Falt }}$

$\mathrm{C}=\mathrm{F}_{\text {in }} \times \mathrm{P}$

Keterangan: $\mathrm{E}_{\text {Out }}$ (Energi output mesin ( $\left.\left.\mathrm{kcal} / \mathrm{jam}\right)\right) ; \mathrm{C}_{\mathrm{b}}$ (Kapasitan mesin (kg / jam)); $\mathrm{E}_{\mathrm{wst}}$ (Energi pada water at saturated temperature $(\mathrm{kj} / \mathrm{kg})) ; \mathrm{E}_{\mathrm{wft}}$ (Energi pada water at feed water temperature $(\mathrm{kj} / \mathrm{kg})) ; \mathrm{E}_{\mathrm{lh}}($ Energi latent heat $(\mathrm{kj} / \mathrm{kg})) ; \mathrm{F}_{\text {in }}$ (Bahan bakar yang dibutuhkan mesin ( $\mathrm{kg} / \mathrm{jam})$ ); $\eta_{\mathrm{b}}$ (Effisiensi mesin boiler; $75 \%$ untuk mesin dengan bahan bakar alternatif; 89\% untuk mesin dengan bahan bakar gas); $\mathrm{E}_{\text {Falt }}$ (Nilai kalori bahan bakar (kkal/kg)); C (Biaya bahan bakar (Rp/jam)); P (Harga bahan bakar $(\mathrm{Rp} / \mathrm{kg}))$.

Analisis finansial terhadap investasi dilakukan dengan menghitung nilai NPV dan IRR yang dihasilkan. Manopo et al. (2013) menuliskan bahwa net present value adalah suatu teknik capital budgeting yang dalam mengukur profitabilitas rencana investasi proyek mempergunakan faktor nilai waktu uang. Sedangkan Rachadian et al. (2013) menyatakan bahwa metode NPV merupakan metode analisis keuangan yang memperhatikan adanya perubahan nilai uang karena faktor waktu; proyeksi arus kas dapat dinilai sekarang (periode awal investasi) melalui pemotongan nilai dengan faktor pengurang yang dikaitkan dengan biaya modal (persentase bunga). Kelebihan metode NPV adalah memasukkan faktor nilai waktu dari uang, mempertimbangkan semua arus kas proyek, dan mengukur besaran absolut dan bukan relatif sehingga mudah mengikuti kontribusinya terhadap usaha meningkatkan kekayaan perusahaan dan pemegang saham (Soeharto 2002). Nilai NPV dan IRR dihitung dengan formula sebagai berikut:

$$
\begin{aligned}
& N P V=\sum_{t=0}^{T} C F_{t} \frac{1}{(1+i)^{t}} \\
& 0=\sum_{t=0}^{T} C F_{t} \frac{1}{(1+I R R)^{t}}
\end{aligned}
$$

Keterangan: NPV (Net present value); $\mathrm{CF}_{\mathrm{t}}$ (Cash flow periode tahun ke t); i (Tingkat bunga); t (Periode waktu); IRR (Internal rate of return).

Analisis teknik dalam penelitian ini diperlukan untuk menghitung besarnya saving yang didapatkan selama menggunakan bahan bakar alternatif sedangkan analisis finansial diperlukan untuk menghitung besarnya investasi yang dikeluarkan oleh perusahaan. Hipotesis dalam penelitian ini adalah sebagai berikut:

HO : Investasi mesin dengan bahan bakar alternatif layak untuk dilakukan

H1 : Investasi mesin dengan bahan bakar alternatif tidak layak untuk dilakukan.

Hipotesis ini diambil dengan pertimbangan bahwa investasi merupakan faktor utama yang menjadi penentu suatu proyek dapat dikerjakan atau tidak dalam suatu perusahaan. Selanjutnya, kerangka berpikir dalam penelitian ini dipilah menjadi dua bagian yaitu bagian teknis dan bagian finansial. Bagian teknis berisi analisis-analisis data teknis mesin yaitu bahan bakar, efisiensi, biaya maintenance, biaya man power dan konsumsi listrik. Sedang bagian finansial berisi analisis tentang NPV, IRR, PP, dan analisis sensitivitas. Kerangka berpikiran penelitian pada Gambar 1.

Tabel 1. Sumber data penelitian

\begin{tabular}{lll}
\hline Jenis data & Sumber data & Teknik pengumpulan data \\
\hline Mesin dengan bahan bakar gas & & \\
Harga mesin & PT. XYZ & study literatur \\
Biaya operasional mesin & PT. XYZ & study literatur \\
Biaya perawatan dan perbaikan & PT. XYZ & study literatur \\
layout & PT. XYZ & observasi lapangan \\
Mesin dengan bahan bakar alternatif & & \\
Harga mesin & PT. GG, PT.TWA, PT.BPE & wawancara \\
Biaya operasional mesin & PT. GG, PT.TWA, PT.BPE & wawancara \\
Biaya perawatan dan perbaikan & PT. GG, PT.TWA, PT.BPE & wawancara \\
layout & PT. GG & observasi lapangan \\
\hline
\end{tabular}




\section{HASIL}

Energi alternatif adalah energi yang dihasilkan oleh bahan bakar yang bersumber dari bahan alternatif. Bahan bakar alternatif tersebut dapat berupa kayu, batu bara, cangkang sawit, kertas, dan serabut kelapa. Dengan menggunakan metode perbandingan eksponensial terhadap mesin dengan bahan bakar gas, alternatif, batu bara dan minyak didapatkan hasil pada Tabel 2. Dalam Tabel 2 terlihat bahwa mesin boiler dengan bahan bakar alternatif cangkang sawit memiliki nilai MPE tertinggi dibanding dengan mesin dengan bahan bakar yang lain, sehingga dalam penelitian ini akan difokuskan pada mesin dengan bahan bakar alternatif tersebut.

Tabel 2. Metode perbandingan eksponensial beberapa jenis mesin boiler

\begin{tabular}{lccccc}
\hline \multirow{2}{*}{ Kriteria } & \multirow{2}{*}{ Bobot } & \multicolumn{4}{c}{ Nilai alternatif mesin } \\
\cline { 3 - 6 } & & Gas & Cangkang sawit & Batu bara & Minyak \\
\hline Investasi & 8 & 7 & 6 & 6 & 7 \\
Pengoperasian & 4 & 7 & 6 & 4 & 7 \\
Biaya perawatan dan perbaikan & 5 & 7 & 6 & 5 & 6 \\
Efisiensi mesin & 6 & 7 & 6 & 5 & 7 \\
Biaya bahan bakar & 8 & 2 & 7 & 8 & 1 \\
Emisi pembakaran & 8 & 7 & 6 & 1 & 5 \\
Penanganan sisa pembakaran & 7 & 8 & 7 & 1 & 8 \\
K3 & 8 & 4 & 8 & 4 & 4 \\
\hline Total skor MPE & & 13.829 .403 & 26.780 .520 & 18.541 .376 & 8.445 .941 \\
\hline
\end{tabular}

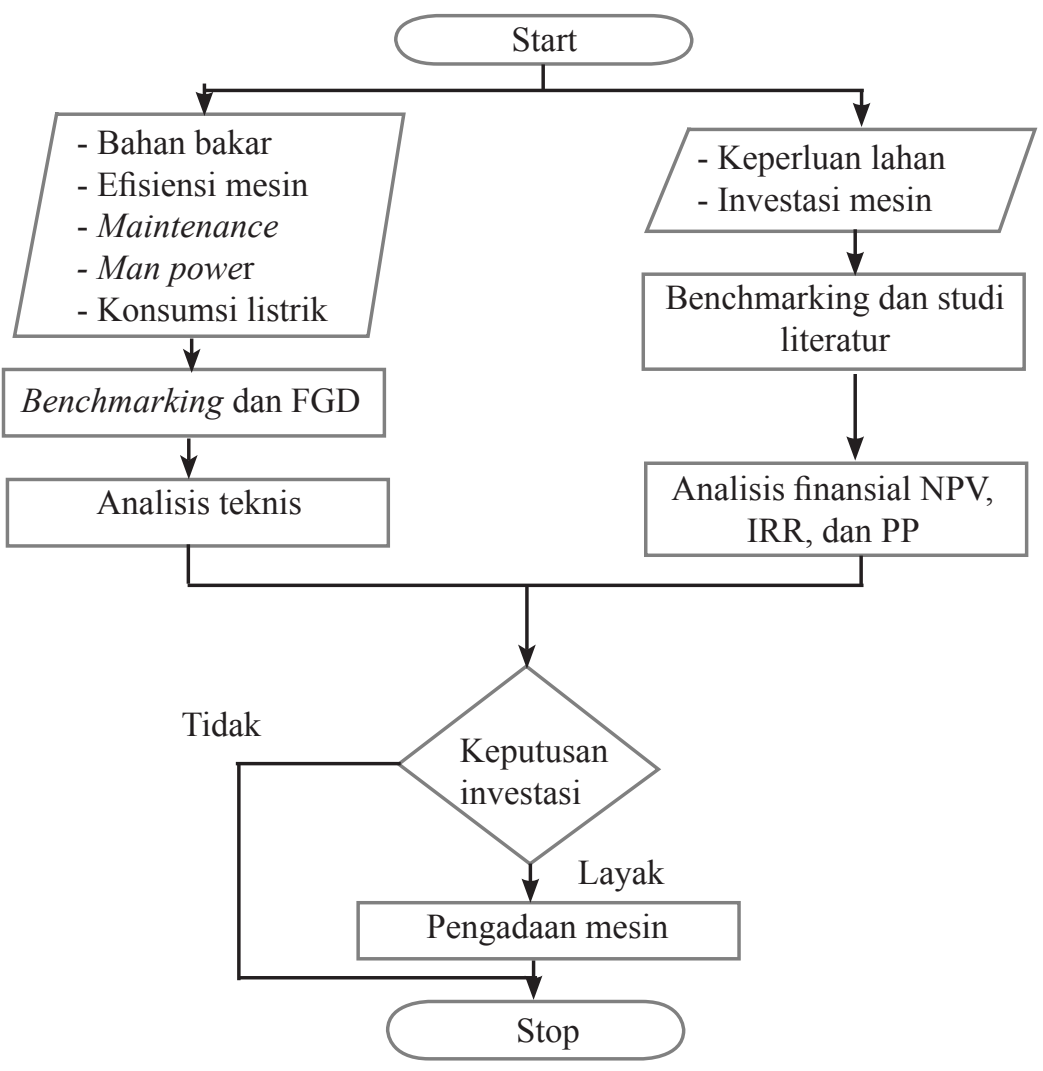

Gambar 1. Kerangka berpikir penelitian 
Investasi dan konsumsi bahan bakar

Dalam Tabel 3 dapat dilihat total investasi mesin dengan bahan bakar alternatif lebih tinggi dibandingkan dengan investasi mesin dengan bahan bakar gas. Kebutuhan lahan untuk mesin dengan bahan bakar alternatif adalah 192 meter persegi sedang mesin dengan bahan bakar gas membutuhkan lahan 72 meter persegi. Ketinggian ruangan untuk mesin dengan bahan bakar alternatif adalah 12 meter sedang mesin dengan bahan bakar gas memerlukan ruangan dengan ketinggian 6 meter. Harga mesin dengan bahan bakar alternatif lebih tinggi dari mesin dengan bahan bakar gas karena terdapat penambahan peralatan berupa tungku pembakaran, dan mesin pengendali debu sisa dari pembakaran bahan bakar alternatif. Instalasi bahan bakar mesin dengan bahan bakar alternatif juga lebih tinggi karena memerlukan sebuah konveyor untuk proses memasukkan bahan bakar.
Pada Tabel 4 dapat dilihat dengan kapasitas yang sama, mesin dengan bahan bakar alternatif memiliki biaya bahan bakar lebih murah. Ini dikarenakan harga per kilogram bahan bakar alternatif lebih murah dibandingkan harga gas per meter kubik.

\section{Biaya-Biaya}

Tabel 5 dapat dilihat biaya per tahun mesin dengan bahan bakar alternatif lebih mahal dikarenakan harga spare part yang lebih mahal dan proses pengerjaan ketika terjadi kerusakan yang lebih sulit. Mesin dengan bahan bakar alternatif membutuhkan biaya tenaga kerja yang lebih besar karena mesin ini dijalankan dengan menggunakan 2 orang tenaga kerja sedang mesin dengan bahan bakar gas membutuhkan 1 orang tenaga kerja. Tabel 6 menunjukkan mesin dengan bahan bakar alternatif memerlukan konsumsi listrik yang lebih tinggi karena memiliki peralatan tambahan yaitu tungku api, konveyor dan pengendali debu yang menggunakan motor listrik sebagai sumber penggerak.

Tabel 3. Perbandingan investasi antara dua jenis mesin

\begin{tabular}{lcc}
\hline \multicolumn{1}{c}{ Investasi } & $\begin{array}{c}\text { Harga mesin dengan bahan bakar gas } \\
(\mathrm{Rp})\end{array}$ & $\begin{array}{c}\text { Harga mesin dengan bahan bakar } \\
\text { alternatif }(\mathrm{Rp})\end{array}$ \\
\hline Lahan & 243.000 .000 & 648.000 .000 \\
Bangunan & 260.425 .000 & 665.520 .000 \\
Mesin & 2.063 .112 .500 & 3.300 .000 .000 \\
Instalasi bahan bakar & 87.867 .000 & 350.000 .000 \\
Total & 2.654 .404 .500 & 4.963 .520 .000 \\
\hline
\end{tabular}

Tabel 4. Biaya bahan bakar per jam

\begin{tabular}{lccccc}
\hline $\begin{array}{c}\text { Bahan bakar } \\
\text { mesin }\end{array}$ & $\begin{array}{c}\text { Kapasitas mesin } \\
(\mathrm{Kg} / \mathrm{jam})\end{array}$ & $\begin{array}{c}\text { Energi output } \\
(\mathrm{Kcal} / \mathrm{Jam})\end{array}$ & $\begin{array}{c}\text { Input bahan bakar } \\
\text { gas : (Nmj/jam) } \\
\text { Alt : (Kg/jam) }\end{array}$ & $\begin{array}{c}\text { Harga satuan } \\
(\mathrm{Rp})\end{array}$ & $\begin{array}{c}\text { Biaya bahan bakar } \\
(\mathrm{Rp} / \mathrm{jam})\end{array}$ \\
\hline Gas & 5.000 & 3.162 .803 & 406 & 4.243 & 1.722 .838 \\
Alternatif & 5.000 & 3.162 .803 & 1.054 & 890 & 938.060 \\
\hline
\end{tabular}

Tabel 5. Biaya per tahun

\begin{tabular}{lcc}
\hline \multicolumn{1}{c}{ Jenis biaya } & Mesin dengan bahan bakar gas & Mesin dengan bahan bakar alternatif \\
\hline Pembelian spare part rata rata per tahun & 25.415 .000 & 42.500 .000 \\
Perawatan rutin tahunan & 20.925 .000 & 50.000 .000 \\
Biaya tenaga kerja per tahun & 37.926 .000 & 75.852 .000 \\
Rata - Rata biaya per tahun & 84.266 .000 & 168.352 .000 \\
\hline
\end{tabular}

Tabel 6. Konsumsi energi listrik

\begin{tabular}{lccc}
\hline \multicolumn{1}{c}{ Mesin dengan bahan bakar } & Total daya $(\mathrm{KW})$ & Harga listrik $(\mathrm{Rp} / \mathrm{Kwh})$ & Konsumsi listrik per jam $(\mathrm{Rp})$ \\
\hline Gas & 11 & 1.253 & 13.157 \\
Alternatif & 77 & 1.253 & 95.855 \\
\hline
\end{tabular}




\section{Jam Kerja Mesin, Jumlah Produksi dan Keperluan Bahan bakar}

Jam kerja mesin atau running hours merupakan indikator lamanya mesin beroperasi untuk membangkitkan uap yang dibutuhkan oleh proses produksi. Dengan menggunakan data produksi selama tahun 2015, dapat ditarik kesimpulan bahwa rata-rata keperluan gas untuk tiap jam operasional mesin boiler di PT XYZ adalah 243,26 meter kubik gas per jam. Sedang keperluan gas tiap ton produk jika dirata-ratakan didapatkan hasil 24,12 meter kubik gas per ton produk.

Dengan menggunakan data pada Tabel 7, dapat dilakukan prediksi jumlah produksi untuk tahun 2017 sampai dengan tahun 2021. Dengan menggunakan regresi linier sederhana didapatkan formula regresi $\mathrm{Y}=22.606,25+6.081,39 \mathrm{X}$. Dengan formula regresi tersebut maka prediksi jumlah produksi tahun 2017 sampai tahun 2021 seperti terlihat dalam Tabel 8.

Dengan menggunakan data jumlah produksi pada Tabel 8, maka dapat dihitung volume gas dan kebutuhan bahan bakar alternatif seperti terlihat dalam Tabel 9. Dengan menggunakan Tabel 9 maka dapat dihitung saving yang didapat antara penggunaan bahan bakar gas dengan bahan bakar alternatif dan dapat dihitung juga nilai NPV dari pengadaan mesin tersebut seperti terlihat pada Tabel 10. Dari nilai NPV dalam Tabel 10 dapat dihitung nilai IRR dari investasi pembelian mesin tersebut. Dari hasil trial and error didapatkan nilai IRR sebesar $49,03 \%$. Sedang payback period dari investasi pengadaan mesin boiler dengan bahan bakar alternatif adalah 2,1 tahun atau 2 tahun 1 bulan 6 hari. Dengan hasil tersebut, maka proyek pengadaan ini layak untuk dilanjutkan.

Tabel 7. Jumlah produksi PT XYZ tahun 2007 sampai 2016

\begin{tabular}{ccccccccccc}
\hline Tahun & 2007 & 2008 & 2009 & 2010 & 2011 & 2012 & 2013 & 2014 & 2015 & 2016 \\
\hline Jumlah produksi (ton) & 23.958 & 29.080 & 34.566 & 41.436 & 44.663 & 51.161 & 59.749 & 66.397 & 68.208 & 80.507 \\
\hline
\end{tabular}

Tabel 8. Prediksi jumlah produksi PT XYZ tahun 2017 sampai 2021

\begin{tabular}{llllll}
\hline Tahun & 2017 & 2018 & 2019 & 2020 & 2021 \\
\hline Jumlah produksi (ton) & 83.420 & 89.502 & 95.583 & 101.664 & 107.746 \\
\hline
\end{tabular}

Tabel 9. Perhitungan keperluan bahan bakar

\begin{tabular}{cccccc}
\hline Tahun & $\begin{array}{c}\text { Produksi } \\
\text { (ton) }\end{array}$ & $\begin{array}{c}\text { Bahan bakar gas } \\
\left(\mathrm{m}^{3}\right)\end{array}$ & $\begin{array}{c}\text { Nilai energi input } \\
(\text { Kkal })\end{array}$ & $\begin{array}{c}\text { Nilai energi output } \\
(\text { Kkal })\end{array}$ & $\begin{array}{c}\text { Bahan bakar } \\
\text { alternatif }(\mathrm{Kg})\end{array}$ \\
\hline 2017 & 83.420 & 2.012 .094 & 17.706 .423 .821 & 15.758 .717 .201 & $5.902 .141,27$ \\
2018 & 89.502 & 2.158 .777 & 18.997 .234 .886 & 16.907 .539 .049 & $6.332 .411,63$ \\
2019 & 95.583 & 2.305 .460 & 20.288 .045 .952 & 18.056 .360 .897 & $6.762 .681,98$ \\
2020 & 101.664 & 2.452 .143 & 21.578 .857 .018 & 19.205 .182 .746 & $7.192 .952,34$ \\
2021 & 107.746 & 2.598 .826 & 22.869 .668 .083 & 20.354 .004 .594 & $7.623 .222,69$ \\
\hline
\end{tabular}

Tabel 10. Net present value investasi mesin dengan bahan bakar alternatif

\begin{tabular}{ccccc}
\hline Tahun & Saving & Selisih biaya-biaya & Discount factor 10,25\% p.a & PV kas bersih \\
\hline 2017 & 3.179 .405 .327 & 574.898 .630 & 0,907 & 2.362 .364 .351 \\
2018 & 3.411 .186 .268 & 632.388 .493 & 0,823 & 2.286 .123 .806 \\
2019 & 3.642 .967 .209 & 695.627 .342 & 0,746 & 2.199 .350 .388 \\
2020 & 3.874 .748 .150 & 765.190 .077 & 0,677 & 2.104 .671 .303 \\
2021 & 4.106 .529 .091 & 841.709 .084 & 0,614 & 2.004 .316 .273 \\
\hline \multicolumn{1}{r}{} \\
\hline
\end{tabular}


Analisis Sensitivitas

Dalam suatu perencanaan proyek, perlu dipertimbangkanbeberapavariabel yangmemungkinkan nilainya dapat berubah sewaktu waktu sehingga mengakibatkan sebuah proyek yang sebelumnya layak untuk dilakukan menjadi tidak layak untuk dilakukan. Dalam penelitian ini, akan menganalisis beberapa variabel yang memungkinkan menyebabkan kegagalan proyek pada PT XYZ. Variabel tersebut meliputi harga bahan bakar alternatif, penurunan jumlah produksi, kenaikan atau penurunan kurs dolar, dan penurunan harga gas.

\section{Harga Bahan Bakar Alternatif}

Perubahan terhadap harga bahan bakar alternatif dapat memengaruhi keputusan layak dan tidaknya investasi dilakukan. Dampak perubahan harga bahan bakar terhadap nilai NPV investasi dapat dilihat dalam Gambar 2. Dari Gambar 2 dapat dilihat bahwa nilai NPV proyek pengadaan mesin boiler di PT XYZ sangat dipengaruhi oleh harga bahan bakar alternatif yang dipergunakan.
Harga tertinggi bahan bakar yang menyebabkan proyek ini menjadi tidak layak untuk dikerjakan adalah pada saat harganya Rp1.128,22. Dengan harga bahan bakar tersebut NPV yang didapatkan dari proyek ini menjadi sangat kecil atau setara dengan nol, ketika harga tersebut semakin naik, nilai NPV nya menjadi minus.

\section{Penurunan Jumlah Produksi}

Jumlah produksi pada kurun waktu beberapa tahun ke depan turut berperan dalam menentukan proyek tersebut layak atau tidak layak untuk dikerjakan. Gambar 3 berikut ini memperlihatkan perubahan nilai NPV pada saat jumlah produksi mengalami penurunan.

Gambar 3 menunjukkan penurunan jumlah produksi dapat menurunkan nilai NPV yang berakibat pengadaan mesin menjadi tidak layak. Batas penurunan jumlah produksi yang dapat di toleransi dalam penelitian ini adalah 44,22 \%, jika penurunan jumlah produksi melebihi angka tersebut maka proyek pengadaan ini menjadi tidak layak.

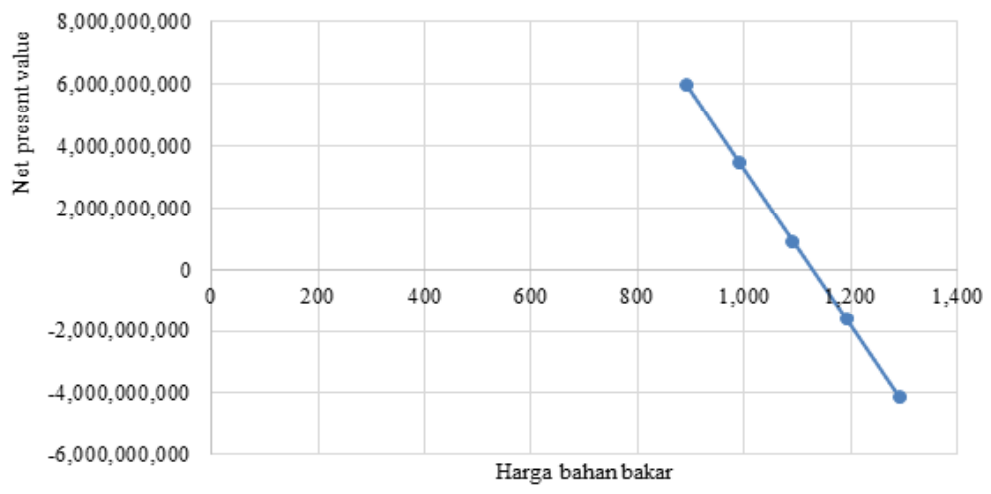

Gambar 2. Perubahan harga bahan bakar terhadap NPV

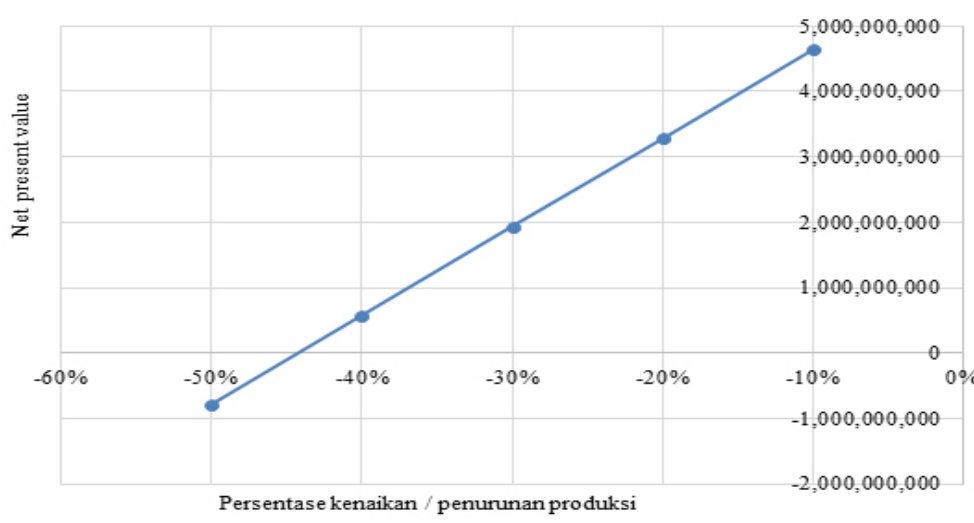

Gambar 3. Penurunan jumlah produksi terhadap NPV 
Dikarenakan pengadaan mesin berbahan bakar alternatif ini dibandingkan dengan mesin berbahan bakar gas, maka perubahan harga bahan bakar gas perlu di analisis apakah dapat memengaruhi tingkat kelayakan proyek pengadaan ini. Gambar 4 memperlihatkan pengaruh penurunan harga gas terhadap nilai NPV.

Dalam Gambar 4 dapat dilihat bahwa harga gas dapat memengaruhi nilai NPV yang dihasilkan, ini dapat terjadi karena perhitungan nilai NPV dalam penelitian ini merupakan selisih yang didapat antara bahan bakar gas dengan bahan bakar alternatif. Ketika harga gas turun melebihi 6,02 dolar per MMBTU maka proyek pengadaan mesin dengan bahan bakar alternatif ini menjadi tidak layak untuk dilakukan.
Penurunan Kurs Dolar

Faktor terakhir yang dianalisis dalam analisis sensitivitas penelitian ini adalah kurs dolar. Dolar amerika merupakan mata uang yang dipergunakan dalam pembelian bahan bakar gas. Harga gas yang di pergunakan dalam penelitian ini adalah harga gas saat ini yang sedang dipergunakan oleh PT XYZ, yaitu 7,56 dolar amerika per MMBTU. Ketika kurs dolar turun, penurunan tersebut dapat berpengaruh terhadap harga gas yang harus di bayar oleh PT XYZ. Penurunan kurs dolar amerika sampai dengan Rp10.345,00 per dolar amerika masih membuat nilai NPV bernilai positif. Jika kurs dolar terus turun di bawah nilai tersebut maka proyek pengadaan mesin di PT XYZ menjadi tidak layak karena nilai NPV nya telah bernilai negatif. Gambar 5 menunjukkan nilai NPV terhadap perubahan kurs dolar amerika.

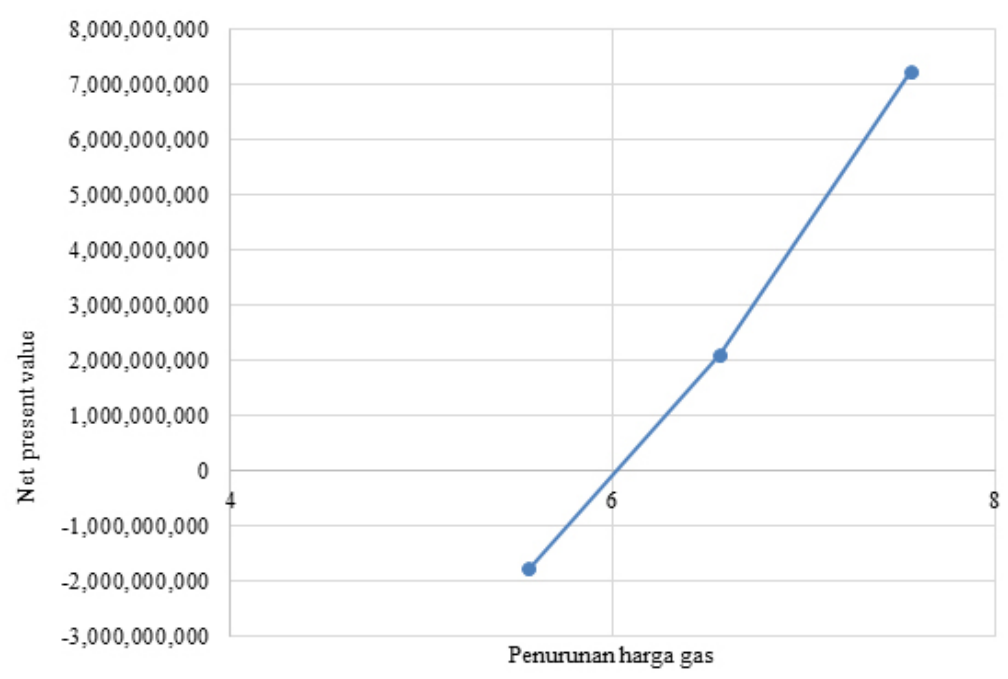

Gambar 4. Penurunan harga gas terhadap NPV

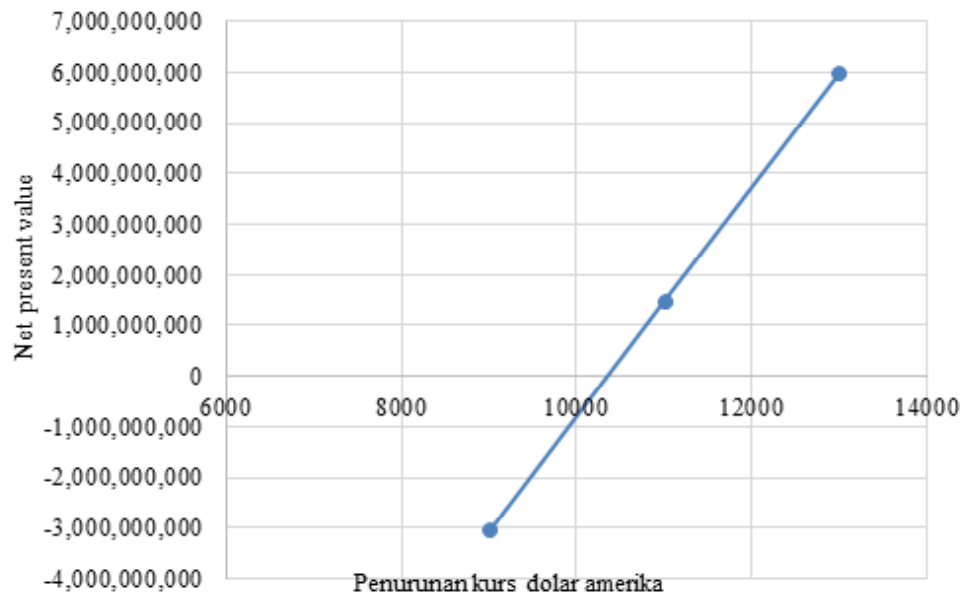

Gambar 5. Perubahan kurs dolar amerika terhadap NPV 


\section{Implikasi Manajerial}

Manfaat yang dapat diambil oleh perusahaan dengan adanya penelitian ini adalah perusahaan memiliki sumber alternatif energi selain minyak dan gas dengan harga yang lebih murah sehingga biaya bahan bakar menjadi lebih rendah. Dengan biaya bahan bakar yang lebih murah maka biaya produksi menjadi lebih rendah sehingga harga produk yang dihasilkan juga lebih murah. Dengan harga yang lebih murah, produk perusahaan dapat lebih bersaing dengan produk dari kompetitor.

\section{KESIMPULAN DAN SARAN}

\section{Kesimpulan}

Dari penelitian yang telah dilakukan terhadap mesin boiler berbahan bakar gas dan berbahan bakar alternatif dapat ditarik kesimpulan yaitu pemakaian bahan bakar alternatif dapat menurunkan ongkos bahan bakar dari semula menggunakan gas yang membutuhkan biaya Rp1.722.838,00 per jam menjadi Rp938.060,00 dengan menggunakan bahan bakar alternatif cangkang sawit. Hasil penelitian dari segi investasi memperlihatkan bahwa pengadaan mesin boiler dengan bahan bakar alternatif memiliki NPV yang bernilai positif yaitu Rp5.993.306.121,00 sehingga proyek pengadaan mesin ini layak untuk dikerjakan. Dalam perhitungan analisis sensitivitas didapatkan kesimpulan bahwa proyek pengadaan mesin ini layak untuk dilanjutkan dengan syarat harga bahan bakar alternatif tidak melebihi Rp1.128,22 per kilogram, penurunan jumlah produksi tidak melebihi $44,22 \%$ dari prediksi, penurunan harga gas tidak lebih rendah dari 6,02 dolar amerika per MMBTU, kurs dolar tidak lebih rendah dari Rp10.345,00 per dolar amerika, dan tingkat suku bunga bank tidak melebihi dari 49,03\%. Penelitian ini merupakan lanjutan dari penelitian-penelitian sebelumnya yang hanya membahas tentang kalori bahan bakar cangkang sawit dan belum ada pembahasan tentang investasi dan harga konversi energi yang dihasilkan oleh bahan bakar cangkang sawit.

\section{Saran}

Penelitian ini terbatas pada segi teknis dan finansial, maka penelitian selanjutnya dapat difokuskan pada sisi sosial terutama masalah kebisingan yang ditimbulkan oleh mesin apakah berpotensi mengganggu kenyamanan warga sekitar serta penelitian pada segi lingkungan yaitu penelitian yang ditujukan terhadap polusi yang ditimbulkan oleh mesin berbahan bakar alternatif terhadap lingkungan sekitar.

\section{DAFTAR PUSTAKA}

Afiyah A, Saifi M, Dwiatmanto. 2015. Analisis studi kelayakan usaha pendirian home industry (studi kasus pada home industri coklat cozy Kademangan Blitar). Jurnal Administrasi Bisnis 23(1): 1-11.

Faishol M, Hastuti S, Ulya M. 2013. Perancangan ulang tata letak fasilitas produksi pabrik tahu srikandi junok Bangkalan. Jurnal AGROINTEK 7(2): 57-65.

Firdaus A, Sirait E. 2015. Analisa pengaruh variasi kapasitas uap terhadap efisiensi ketel uap di PT Sinar Sosro Banyuasin-Sumatera Selatan. Jurnal Energi dan Manufaktur 8(2): 111-230.

Hanamane MD, Attar KD, Mudholkar RR. 2013. Embedded fuzzy module for sugar industrial boiler parameter control. International Journal of Soft Computing and Engineering (IJSCE) 3(2): 165-168.

Hao L. 2014. Influence and optimizing of boiler energi. Applied Mechanics and Materials 707(2015): 352-355.

Haryanto, Bakar A, Muis L. 2015. Upaya pembinaan masyarakat dalam mengembangkan briket arang cangkang sawit sebagai alternatif bahan bakar di kecamatan Sungai Bahar kabupaten Muaro Jambi. Jurnal Pengabdian Masyarakat 30(4): 30-35.

Jufrida F, Syechalad N, Nasir M. 2016. Analisis pengaruh investasi asing langsung (FDI) dan investasi dalam negeri terhadap pertumbuhan ekonomi Indonesia. Jurnal Perspektif Ekonomi Darussalam 2(1): 54-68. https://doi. org/10.24815/jped.v2i1.6652.

Kasmir, Jakfar. 2013. Studi Kelayakan Bisnis. Ed ke-9. Jakarta: Kharisma Putra Utama.

Khaidir. 2016. Pengolahan limbah pertanian sebagai bahan bakar alternatif. Jurnal Agrium 13(2): 63-68.

Manopo SFJ, Tjakra J, Mandagi RJM, Sibi M. 2013. Analisis biaya investasi pada perumahan griya paniki indah. Jurnal Sipil Statik 1(5): 377-381.

Marimin. 2004. Teknik dan Aplikasi Pengambilan Keputusan Kriteria Majemuk. Ed ke-1. Jakarta: 
Grasindo.

Nurlita A. 2014. Investasi pasar modal syariah dalam kajian islam. Jurnal Penelitian Sosial Keagamaan 17(1): 2-20.

Palaloi S. 2014. Analisis potensi penghematan energi pada boiler di pabrik tekstil. Seminar nasional aplikasi sains dan teknologi (SNAST); 2014 november 15; Yogyakarta, Indonesia. Yogyakarta.

Rachadian FM, Agassi EA, Sutopo W. 2013. Analisis kelayakan investasi penambahan mesin frais baru pada CV.XYZ.J@ti Undip 8(1):15-20.

Ratnasari E, Hantoro R, Hamidah NL. 2014. Desain economizer untuk meningkatkan efisiensi boiler 52 B 1/2/3 pada unit utilities complex di PT Pertamina RU IV Cilacap. Jurnal Teknik Pomits 1(1): $1-5$.

Rifai Y, Fauzi AM, Rusli MS. 2016. Overall equipment effrectiveness dalam peningkatan kinerja produksi ban PT Goodyear Indonesia. Jurnal Aplikasi Bisnis dan Manajemen 2(2): 148-160. https://doi.org/10.17358/JABM.2.2.148.
Roslim MK, Hassan, Izzati K. 2014. Experimental and simulation study on the effects of twisted coil plates on the performance of fire tube boiler. Applied Mechanism and Materials 564(2014): 234-239.https://doi.org/10.4028/www. scientific.net/AMM.564.234.

Siregar R, Sukatendel D, Tarigan U. 2013. Perancangan ulang tataletak fasilitas produksi dengan menerapkan algoritma blockplan dan algoritma corelap pada PT.XYZ. e-Journal Teknik Industri FT USU 1(1): 35-44.

Soeharto I. 2002. Studi Kelayakan Proyek Industri. Sumiharti Y, editor. Jakarta: Erlangga.

Wang X, Xiao H, Ning X, Dai Y. 2014. Influence of air distribution modes on boiler efficiency. Applied Mechanism and Materials 733(2015): 517-521. https://doi.org/10.4028/www.scientific.net/ AMM.733.517.

Yamashita Y, Kanamori K, Ohwada H. 2012. Creating layout system in prototype less production system. International Journal of Machine Learning and Computing 2(6): 776-781. https:// doi.org/10.7763/IJMLC.2012.V2.235. 